\title{
PELAKSANAAN PERLINDUNGAN TENAGA KERJA SEBAGAI WUJUD KEPASTIAN HUKUM
}

\author{
Sami'an \\ Fakultas Ekonomi Universitas Semarang \\ samian@usm.ac.id
}

Diterima: Agustus 2019, Disetujui: September 2019, Dipublikasikan: Oktober 2019

\begin{abstract}
Companies can pay more attention to workforce activities so that companies are more competitive. Workplace problems, especially regarding worker / labor protection. Generally, workers / laborers get lower salaries. Social security is minimal, and even workers are considered a factor of production.the writer wants to analyze whether it is true that the worker / laborer is treated not in accordance with his dignity and status as a human being with the absence of legal certainty and legal protection for workers / laborers in terms of indonesian labor law, namely law number 13 year 2003. This research method is based on data collected from library materials (secondary data) and field (primary data / basic data). Secondary data is obtained through literature study, namely by collecting written materials related to the topics discussed in the form of legislation, books, papers, research results, journals, magazines, internet, and so on. While the primary data or basic data of the author can be from the jakarta legal aid institute. The data is the main source for this writing. From the results the authors found that it was true that the jakarta legal aid institute received complaints. Justice seekers are very disadvantaged, even though it has been regulated in the manpower act. This is due to unclear formulation of employment relations between employers, service providers and workers / laborers.
\end{abstract}

Keyword : Implementation; Legal protection; Labor; Legal certainty

\begin{abstract}
Abstrak
Perusahaan dapat lebih memperhatikan kegiatan tenaga kerja sehingga perusahaan lebih kompetitif. Masalah tenga kerja, khususnya mengenai perlindungan pekerja/buruh. Umumnya, pekerja/buruh mendapatkan gaji yang lebih rendah. Jaminan sosial yang diterima minimal, dan bahkan pekerja/buruh dianggap sebagai faktor produksi. Penulis ingin menganalisis apakah benar bahwa pekerja/buruh tersebut diperlakukan tidak sesuai dengan harkat dan martabatnya sebagai manusia dengan tidak adanya kepastian hukum dan perlindungan hukum bagi pekerja/buruh yang ditinjau dari sudut hukum ketenagakerjaan Indonesia, yakni UU Nomor 13 Tahun 2003. Metode penelitian ini didasarkan atas data yang terkumpul dari bahan-bahan pustaka (data sekunder) dan lapangan (data primer/data dasar). Data sekunder diperoleh melalui studi kepustakaan, yaitu dengan mengumpulkan bahan-bahan tertulis yang berhubungan dengan topik yang dibahas berupa peraturan perundang-undangan, buku, makalah, hasil penelitian, jurnal, majalah, internet, dan sebagainya. Sedangkan data primer atau data dasar penulis dapat dari Lembaga Bantuan hukum Jakarta. Data tersebut merupakan
\end{abstract}


sumber utama bagi penulisan ini. Dari hasil penulis menemukan bahwa benar Lembaga Bantuan Hukum Jakrta menerima pengaduan. Pencari Keadilan sangat dirugikan, sekalipun telah diatur dalam Undang-Undang Ketenagakerjaan. Hal ini karena ketidakjelasan perumusan hubungan kerja antara pemberi pekerjaan, penyedia jasa dengan pekerja/buruh.

Kata Kunci: Pelaksanaan; Perlindungan Hukum; Tenaga kerja; Kepastian Hukum.

\section{PENDAHULUAN}

Berdasarkan UUD 1945 Pasal 27 ayat (2) dan 28D ayat (2), yang menyebutkan warga negara Indonesia berhak atas pekerjaan, upah, dan penghidupan yang layak. Menurut Pasal 1 angka 4 Undang-Undang ketenagakerjaan 2003, yang dinamakan pemberi kerja adalah perseorangan, pengusaha, badan hukum atau badan-badan lainnya yang mempekerjakan tenaga kerja dengan membayar upah atau imbalan dalam bentuk lain. Sedangkan pengertian tenaga kerja terdapat dalam Pasal 1 angka 2 UndangUndang ketenagakerjaan 2003, yaitu setiap orang yang mampu melakukan pekerjan guna menghasilkan barang dan/jasa baik untuk memenuhi kebutuhan sendiri maupun untuk masyarakat.

Dalam Pasal 1 Angka 5 Undang-Undang Ketenagakerjaan Nomor 13 Tahun 2003 disebutkan bahwa yang dimaksud dengan Pengusaha adalah :

a) Orang perseorangan, persekutuan, atau badan hukum yang menjalankan suatu perusahaan milik sendiri;

b) Orang perseorangan, persekutuan, atau badan hukum yang secara berdiri sendiri menjalankan perusahaan bukan miliknya;

c) Orang perseorangan, persekutuan, atau badan hukum yang berada di Indonesia mewakili perusahaan sebagaimana dimaksud dalam huruf $a$ dan $b$ yang berkedudukan di luar wilayah Indonesia;

Sedangkan yang dimaksud dengan Perusahaan menurut Pasal 1 angka 6 UndangUndang Ketenagakerjaan Nomor 13 Tahun 2003 adalah :

a. Setiap bentuk usaha yang berbadan hukum atau tidak, milik orang perseorangan, milik persekutuan atau milik badan hukum, baik swasta maupun milik negara yang memperkerjakan pekerja/buruh dengan membayar upah atau imbalan dalam bentuk lain; 
b. Usaha-Usaha sosial dan usaha-usaha lain yang mempunyai pengurus dan memperkerjakan orang lain dengan membayar upah atau imbalan dalam bentuk lain.

Dalam pelaksanaan pembangunan di Indonesia sekarang yang menitikberatkan pada pembangunan dalam bidang ekonomi, hukum mempunyai fungsi yang sangat penting dalam menunjang kemajuan perekonomian di Indonesia. Pelaksanaan Pembangunan dengan penekanan yang lebih menonjol kepada segi pemerataan.

Pembangunan adalah usaha untuk menciptakan kemakmuran dan kesejahteraan rakyat. Oleh karena itu hasil-hasil pembangunan harus dapat dinikmati seluruh rakyat sebagai peningkatan kesejahteraan lahir dan batin secara adil dan merata. Sebaliknya, berhasilnya pembangunan tergantung partisipasi seluruh rakyat, yang berarti pembangunan harus dilaksanakan secara merata oleh segenap lapisan masyarakat(FX Djumiadji 1987:1).

Pembangunan dapat dilaksanakan dan berhasil jika situasi Nasional mantap. Makin mantap stabilitas Nasional, makin lancar usaha pembangunan. Pemerataan, pertumbuhan dan stabilitas adalah unsur yang saling berkaitan, karena itu dalam pelaksanaan pembangunan harus senantiasa diusahakan keseimbangan yang serasi antara ketiga unsur tersebut.

Hampir setiap bidang kehidupan sekarang ini diatur oleh peraturan - peraturan hukum. Melalui penormaan terhadap tingkah laku manusia ini hukum menelusuri hampir semua bidang kehidupan manusia. Campur tangan hukum yang semakin meluas kedalam bidang kehidupan masyarakat memyebabkan masalah efektivitas penerapan hukum menjadi semakin penting untuk diperhitungkan. Itu artinya hukum harus bisa menjadi institusi yang bekerja secara efektif di dalam masyarakat.

Bagi suatu masyarakat yang sedang membangun, hukum selalu dikaitkan dengan usaha-usaha untuk meningatkan taraf kehidupan masyarakat kearah yang lebih baik, sebab melalui norma hukum yang dimaksud maka diharapkan ketertiban dan kepastian dapat terpenuhi sehingga mampu mewujudkan apa yang dicita-citakan dalam kehidupan masyarakat.

Kriminalisasi terhadap pekerja dan pemberangusan hak untuk berserikat. Dalam Catatan Akhir Tahun yang dirilis Lembaga Bantuan Hukum (LBH) Jakarta, tercatat selama 2015 ada 244 pengaduan untuk kasus perburuhan. Pada 2016 LBH Jakarta 
menangani lebih lanjut 41 kasus dengan 570 pencari keadilan. Pada 2017, LBH Jakarta bahkan menerima 223 pengaduan dengan 4.565 pencari keadilan.

Hubungan kerja adalah hubungan antara pekerja dengan pengusaha yang terjadi setelah adanya perjanjian kerja. Dalam Pasal 1 angka 15 Undang-Undang No. 13 Tahun 2003 tentang Ketenagakerjaan disebutkan bahwa hubungan kerja adalah hubungan antara pengusaha dengan pekerja/buruh berdasarkan perjanjian kerja yang mempunyai unsur pekerjaan, upah, dan perintah. Hubungan kerja terjadi karena adanya perjanjian kerja antara pengusaha dan pekerja/buruh (Lalu Husni, 2007: 53). Dari pengertian tersebut jelaslah bahwa hubungan kerja sebagai bentuk hubungan hukum lahir atau tercipta setelah adanya perjanjian kerja antara pekerja dan pengusaha.

Ketentuan-ketentuan hukum yang dapat dijadikan payung agar apa yang dilakukan sebagai suatu bentuk usaha yang memberikan rasa aman sebab selaku pelaku bisnis ketertiban dan kepastian hukum harus mampu mengemban misi dengan sebaik-baiknya, apalagi bila perhatian yang tertuju pada persoalan globalisasi perdagangan yang merupakan persaingan pasar terbuka yang menjadi kata kunci yang paling krusial.

\section{KAJIAN PUSTAKA}

\section{Perlindungan Tenaga Kerja}

Pemikiran teori negara kesejateraan ini diakomodir dalam pembukaan UUD Negara RI Tahun 1945.Dengan demikian maka dalam konteks hubungan kerja tersebut tidak lepas dari peran dan tujuan Negara sehinggga dapat dicegah terjadinya eksploitasi oleh pihak pengusaha terhadap buruh dalam hubungan kerja.Buruh sebagai pihak yang lemah, sarat keterbatasan selayaknya mendapatkan perlindungan hukum, disamping wajib sebagai hak konstitusional. Hak-hak yang dapat dikategorikan sebagai hak konstitusional buruh antara lain: dalam pasal 27 ayat (2) UUD 45 yang menyatakan, "Tiap-tiap warga Negara berhak atas pekerjaan dan penghidupan yang layak bagi kemanusiaan.

Kedudukan negara yang sentral dalam tata kehidupan bersama dapat dijelaskan dengan alasan pembenarannya.Mengingat di samping negara sudah ada kehidupan bersama lainnya yaitu masyarakat yang sudah lebih tua usianya dari negara.Studi ilmu 
hukum berkaitan erat dengan penetapan kaedah normatif, untuk menjadi acuan dalam membentuk suatu Negara dan cara menjalankannya(Agus Pramono, 2011:393)

Perlindungan hukum mempunyai makna sebagai perlindungan dengan menggunakan sarana hukum atau perlindungan yang diberikan oleh hukum, ditujukan kepada perlindungan terhadap kepentingan-kepentingan tertentu, yaitu dengan cara menjadikan kepentingan yang perlu dilindungi tersebut ke dalam sebuah hak hukum.

Dalam ilmu hukum "Hak" disebut juga hukum subyektif, Hukum subyektif merupakan segi aktif dari pada hubungan hukum yang diberikan oleh hukum obyektif (normanorma, kaidah, recht).

Salah satu tujuan pembangunan ketenagakerjaan adalah memberikan perlindungan kepada pekerja/buruh dalam mewujudkan kesejahteraan, yaitu sebagaimana yang telah diatur dalam Pasal 4 huruf c UU Ketenagakerjaan. Lingkup perlindungan terhadap pekerja/ buruh yang diberikan dan diatur dalam UU Ketenagakerjaan. Perlindungan atas hak-hak dasar pekerja. Obyek perlindungan ini adalah sebagai berikut:

1) Perlindungan pekerja/ buruh perempuan Perlindungan terhadap pekerja/buruh perempuan berkaitan dengan: Batasan waktu kerja bagi yang berumur kurang dari 18 (delapan belas) tahun, yaitu sebagaimana diatur dalam Pasal 76 ayat (1) Undang-undang Ketenagakerjaan; Larangan bekerja bagi wanita hamil untuk jamjam tertentu, yaitu sebagaimana diatur dalam Pasal 76 ayat (2) Undang-undang Ketenagakerjaan; Syarat dan ketentuan yang harus dipenuhi oleh pengusaha apabila mempekerjakan perempuan antara pukul 23.00 sampai dengan pukul 07.00, yaitu sebagaimana diatur dalam Pasal 76 ayat (3) Undang-undang Ketenagakerjaan; Kewajiban bagi pengusaha menyediakan angkutan antar jemput bagi yang bekerja antara pukul 23.00 sampai dengan pukul 07.00, yaitu sebagaimana diatur dalam Pasal 76 ayat (4) Undang-undang Ketenagakerjaan.

2) Perlindungan terhadap pekerja/buruh anak. Yang termasuk ke dalam pekerja/buruh anak adalah mereka atau setiap orang yang bekerja yang berumur dibawah 18 (delapan belas) tahun, sebagaimana diatur dalam Pasal 1 butir 26 Undang-undang Ketenagakerjaan. Perlindungan terhadap pekerja/buruh anak meliputi hal-hal atau ketentuan tentang tata cara mempekerjakan anak, sebagaimana diatur dalam Pasal 68, 69 ayat (1) dan ayat (2), Pasal 72, Pasal 73 dan Pasal 74 ayat (1) UU Ketenagakerjaan. 
3) Perlindungan bagi penyandang cacat. Pengusaha yang mempekerjakan tenaga kerja penyandang cacat wajib memberikan perlindungan sesuai dengan jenis dan derajat kecacatan, sebagaimana diatur dalam Pasal 76 ayat (1) UU Ketenagakerjaan. Bentuk perlindungan tersebut adalah seperti penyediaan aksesibilitas, pemberian alat kerja dan pelindung diri.

Perlindungan atas Keselamatan dan Kesehatan Kerja. Perlindungan atas keselamatan dan kesehatan kerja merupakan salah satu hak dari pekerja atau buruh seperti yang telah diatur dalam ketentuan Pasal 86 ayat (1) huruf UU Ketenagakerjaan. Untuk itu pengusaha wajib melaksanakan secara sistematis dan terintegrasi dengan sistem manajemen perusahaan. Perlindungan ini bertujuan untuk melindungi keselamatan pekerja/buruh guna mewujudkan produktivitas kerja yang optimal, dengan cara pencegahan kecelakaan dan penyakit akibat kerja, pengendalian cahaya ditempat kerja, promosi kesehatan, pengobatan dan rehabilitasi.

Perlindungan atas Jaminan Sosial Tenaga Kerja. Pengertian dari Jaminan Sosial Tenaga Kerja sebagaimana diatur pada Pasal 1 ayat (1) Undangundang Nomor 3 Tahun 1992 tentang Jaminan Sosial Tenaga Kerja, adalah suatu perlindungan bagi pekerja/buruh dalam bentuk santunan berupa uang sebagai pengganti sebagian dari penghasilan yang hilang atau berkurang dan pelayanan sebagai akibat peristiwa atau keadaan yang dialami oleh pekerja/buruh berupa kecelakaan kerja, sakit, hamil, bersalin, hari tua, dan meninggal dunia. Perlindungan ini merupakan perlindungan ekonomis dan perlindungan sosial, sebagaimana diatur dalam Pasal 3 ayat (2), Pasal 4 ayat (1), Pasal 8 ayat (2), Pasal 12 ayat (1), Pasal 14 dan Pasal 15 serta Pasal 16 Undang-undang Nomor 3 Tahun 1992 tentang Jaminan Sosial Tenaga Kerja.

Perlindungan atas Upah. Pengupahan merupakan aspek yang sangat penting dalam perlindungan pekerja/buruh. Hal ini secara tegas diamanatkan dalam Pasal 88ayat (1) Undang-undang Ketenagakerjaan bahwa setiap pekerja/buruh berhak memperoleh penghasilan yang memenuhi penghidupan yang layak bagi kemanusiaan. Lebih lanjut dalam penjelasan dari Pasal88ayat(1)UU Ketenagakerjaan diterangkan,bahwa yang dimaksud dengan penghasilan yang memenuhi penghidupan yang layak adalah jumlah penerimaan atau pendapatan pekerja/buruh dari hasil pekerjaannya sehingga mampu memenuhi kebutuhan hidup pekerja/buruh dan keluarganya secara wajar yang meliputi makanan dan minuman, sandang, perumahan, pendidikan, kesehatan, rekreasi dan 
jaminan hari tua. Upah yang dibayarkan kepada pekerja/buruh harus memenuhi ketentuan upah minimun, sesuai dengan Pasal 1 ayat (1) Peraturan Menteri Tenaga Kerja Nomor Per01/Men/1999 tentang Upah Minimum, yang dimaksud dengan upah minimum adalah upah bulanan yang terendah, terdiri dari upah pokok dan tunjangan tetap.

Kedudukan pekerja pada hakikatnya dapat ditinjau dari dua segi, yaitu segi yuridis dan dari segi sosial ekonomis. Dari segi sosial ekonomis, pekerja membutuhkan perlindungan hukum dari negara atas kemungkinan adanya tindakansewenang-wenang dari pengusaha. Bentuk perlindungan yang diberikan pemerintah adalah dengan membuat peraturan-peraturan yang mengikatburuh dan majikan, mengadakan pembinaan, serta melaksanakan proses hubungan industrial. Hubungan industrial pada dasarnya adalah proses terbinanya komunikasi, konsultasi musyawarah serta berunding dan ditopang oleh kemampuan dan komitmen yang tinggi dari semua elemen yang ada

\section{Kepastian Hukum Tenaga Kerja/buruh}

Hubungan perburuhan (labour relation) yang kondusif akan dapat meningkatkan iklim bisnis dan investasi yang favorable dimana padaakhirnya sangat berpengaruhi terhadap jalannya roda perekonomian.Hubungan antara buruh dan penngusaha atau majikan atau pemodalselama ini lebih menunjukkan hubungan yang antagonistik daripada hubungan yang harmonis.

Cita-cita mewujudkan hubungan yang industrial atau jugahubungan perburuhan yang sejahtera sebagaimanaselalu diamanatkan dalam berbagai perundang-undangan perburuhantidak pernah terwujud.Di mana sebenarnya masalah pokoknya,sehingga hubungan hubungan harmonis itu tidak pernah terwujud.

Beberapa masalah pokok yang menjadi pemicu menguatnyaantagonisme hubungan perburuhan sebagai berikut :

a. Masalah Kebebasan Berserikat

Mengkaji masalah perburuhan tidak akan terlepas dari keberadaan serikat pekerja dan juga pemogokan, yang keduanyamerupakan hak setiap pekerja yang dilindungi oleh perundangundangan.Eksistensinya pun telah diakui oleh Undangundang No. 21Tahun 2000 tentang Serikat Pekerja atau Serikat Buruh.Untuk menghadapi kemungkinan tindakan yang tidak adil daripengusaha, para pekerja bergabung dengan serikat pekerja untukmemperjuangkan aspirasinya. Serikat 
pekerja akan mewakili danmemperjuangkan suara hak-hak pekerja yang bergabung, atau yang tidak bergabung dengan serikat pekerja itu. Hal inilah yang disebut dengan collective bargaining. Rasio dari aspirasi secara kolektifdibandingkan dengan secara individual adalah bahwa posisi pekerjaakan lebih kuat apabila mereka secara kolektif bernegosiasi denganpengusaha, dibandingkan secara individual.

b. Kelayakan Upah

Kelayakan Upah adalah masalah yang juga menjadi pemicuhubungan antagonistik antara buruh dan pengusaha.Masalah upahbiasanya menjadi materi yang dinegosiasikan oleh serikat buruh atauserikat pekerja.Pengupahan, meskipun telah ada undang-undang yang mengaturnya, tetap saja menjadi pemicu.Karena bagaimanapun untuk mencapai margin usaha yang besar, sebuah perusahaanharus menekan sedapat mungkin biaya operasional perusahaan,yang salah satu komponennya adalah upah buruh. Undang-undang No. 13 Tahun 2003 menyebutkan, setiap pekerja atau buruh berhak memperoleh penghasilan yang memenuhi penghidupan yang layakbagi kemanusiaan (Pasal 88, ayat 1).Artinya secara normatif buruhberhak atas penghidupan yang layak dan memenuhi standar minimumkebutuhan buruh. Dalam prakteknya, akibat buruh yang dianggap tidak mengertisoal hukum, pelanggaran atas aturan pengupahan ini banyakterjadi di perusahaan.Apalagi daya tawar buruh yangsemakin rendah di tengah krisis ekonomi.Tidak jarang sesama buruhterjadi perpecahan akibat ketidakserempakan dalam menghadapi tuntutan pengupahan.

Perbedaan penafsiran upah minimum antara buruh dan pengusaha adalah menjadi masalah yang mengakibatkan hubunganburuh semakin tidak harmonis. Dalam undang-undang yangbaru, disebutkan sebagai berikut:

Pasal 88 Undang-undang No. 13 Tahun 2003 menyebutkanbahwa:

(1) upah minimum sebagaimana dimaksud dalam Pasal 88 ayat 3 huruf a dapat terdiri atas :

a. Upah minimum berdasarkan wilayah provinsi atau kabupaten / kota.

b. Upah minimum berdasarkan sektor pada wilayah provinsi atau kabupaten / kota. 
(2) upah minimum sebagaimana dimaksud dalam ayat (1)diarahkan kepada pencapaian kebutuhan hidup yanglayak.

(3) upah minimum sebagaimana dimaksud dalam ayat(1) ditetapkan oleh Gubernur dengan memperhatikanrekomendasi dari dewan Pengupahan Provinsi dan atauBupati / Walikota.

(4) komponen serta pelaksanaan terhadap pencapaiankebutuhan hidup yang layak sebagaimana dimaksuddalam ayat (2) diatur dengan Keputusan Menteri.

Aturan pengupahan sebagaimana disebutkan diatas, jelastidak menunjukkan suatu ketegasan tentang standar kebutuhan fisikmanusia.Karena itu penyusunan peraturan operasional harus dibuat.Sebagai gambaran, protes buruh atas pengupahan itu telah terjadicukup panjang.Di zaman Orde Baru misalnya, kebijakan pengupahansangat jauh dari rasa keadilan.Konsep nilai kerja yang dalam logikaekonomi berkedudukan simetris dengan hasil, menjadi nilai kerja yangtidak bermakna.Bahkan sejak tahun 1969 lembaga bernama Dewan Pengupahan Nasional berwenang menentukan tingkat upah buruhtanpa didasarkan pada hukum permintaan-penawaran tenaga kerja dipasar.

c. Pemutusan Hubungan Kerja (PHK)

Pemutusan hubungan kerja adalah hal yang paling ditakuti oleh para buruh atau pekerja. Undang-undang No. 13 Tahun 2003, yangjuga ditentang oleh banyak serikat buruh, telah melapangkan jalanbagi mudahnya PHK terhadap buruh. Kemudahan ini terjadi akibatdihapuskannya keharusan pengusaha untuk meminta izin melakukanPHK kepada Panitia Penyelesaian Perselisihan Perburuhan Daerah dan Pusat yang berada di bawah Departemen Tenaga Kerja,sebagaimana diatur sebelumnya dalam Undangundang No. 22 Tahun1957 tentang Penyelesaian Perselisihan Perburuhan.

Dalam pasal 10 disebutkan, PHK yang dilakukan tanpa memperoleh izin batal demihukum. Undang-undang yang baru, telah mengalihkan mekanismepenyelesaian perburuhan dari P4 Daerah atau Pusat kepada sebuahlembaga yang disebut dengan pengadilan Industrial yang akan menjadisebuah kamar khusus di Pengadilan Negeri. Proses penyelesaianperselisihan perburuhan pun kemudian akan menjadi subyek 
dariprosedur hukum dalam hukum perdata. Pasal 151 ayat 3 Undang-undang No. 13 Tahun 2003 menyebutkan "dalam hal perundingan sebagaimana dimaksud dalam ayat (2) benar-benartidak menghasilkan persetujuan, pengusaha hanya dapatmemutuskan hubungan kerja dengan pekerja atau buruh setelahmemperoleh penetapan dari lembaga penyelesaian perselisihanhubungan industrial.

Dengan dihapuskannya P4, keharusan meminta izin untuk PHKpun menjadi hilang. Keterlibatan organisasi buruh dan pengusahadiakomodasi melalui sistem "hakim ad hoc"yang berasal dari unsurburuh dan pengusaha. Sementara sebagian besar keluhan buruhakan ditangani melalui "arbitrase sukarela" melalui forum yang disebut"forum bipartit" atau lembaga kerjasama bipartit antara pengusahadengan buruh sebagai pribadi di tempat kerja masing-masing.

Dari uraian di atas dapat dilakukan justifikasi, Hubungan hukum antara pekerja dan perusahaan penyedia jasa itu sendiri dimuat dalam perjanjian kerja yang berisikan tentang hak dan kewajiban antara perusahaan dengan karyawannya sedangkan hubungan hukum antara perusahaan penyedia tenaga kerja dengan Perusahaan pemberi pekerjaan dimuat dalam perjanjian kerjasama yang sudah disepakati oleh kedua belah pihak sesuai dengan ketentuan Undang-Undang Nomor 13 Tahun 2003 tentang Ketenagakerjaan dan Kitab Undang-Undang Hukum Perdata.perjanjian kerja merupakan dasar terjadinya hubungan kerja. Perjanjian kerja yang dialakukan oleh pekerja dengan pengusaha/ pemberi kerja harus memenuhi ketentuan asas-asas hukum kontrak dan syarat-syarat perjanjian kerja baik yang materiil maupun yang formil.Perjanjian kerja harus memenuhi ketentuan asas-asas hukum kontrak, yang meliputi asas konsensualisme, asas kebebasan berkontrak dan asas kekuatan mengikatnya perjanjian.Pada asas kebebasan berkontrak, terdapat kebebasan kehendak yang mengimplikasikan adanya kesetaraan minimal. Di sini antara pekerja dengan pemberi kerja harus mempunyai kedudukan yang sama tidak dalam kedudukan subordinasi (di bawah perintah) harus sebagai mitra kerja. Pada asas kekuatan mengikatnya kontrak, ditentukan oleh isi kontrak itu sendiri, kepatutan atau iktikad baik, kebiasaan dan peraturan perundang-undangan. Sebaiknya pemerintah merevisi UU Ketenagakerjaan dan melarang tenaga kerja Outsourcing di berlakukan di perusahaanperusahaan atau menghapus Permennakertrans No. 19 Tahun 2012 Tentang Syaratsyarat penyerahan sebagian pelaksanaan Pekerjaan Kepada Perusahaan Lain. 
Pemerintah harus tegas dan harus mampu mengakomodir usulan-usulan dari pihak Organisasi-organisasi buruh yang sering menyuarakan tentang keadilan dan kesejahteraan buruh.Jangan hanya dijadikan corong dan melindungi pengusaha saja, tapi juga harus memperhatikan rasa keadilan dan kesejahteraan kaum buruh.

\section{Kerangka Pemikiran}

Perusahaan yang mempekerjakan pekerja/buruh harus sesuai dengan UU No. 13 Tahun 2003 tentang ketenagakerjaan, pekrja/buruh serikat pekerja dan pemerintah melakukan pengawasan terhadap perusahaan terkait dengan perlindungan tenaga kerja yang bekerja di suatu perusahaan. Pekerja/buruh mendapatkan hak- haknya sehingga pekerja/ buruh ada kepastian hukum yang jelas.

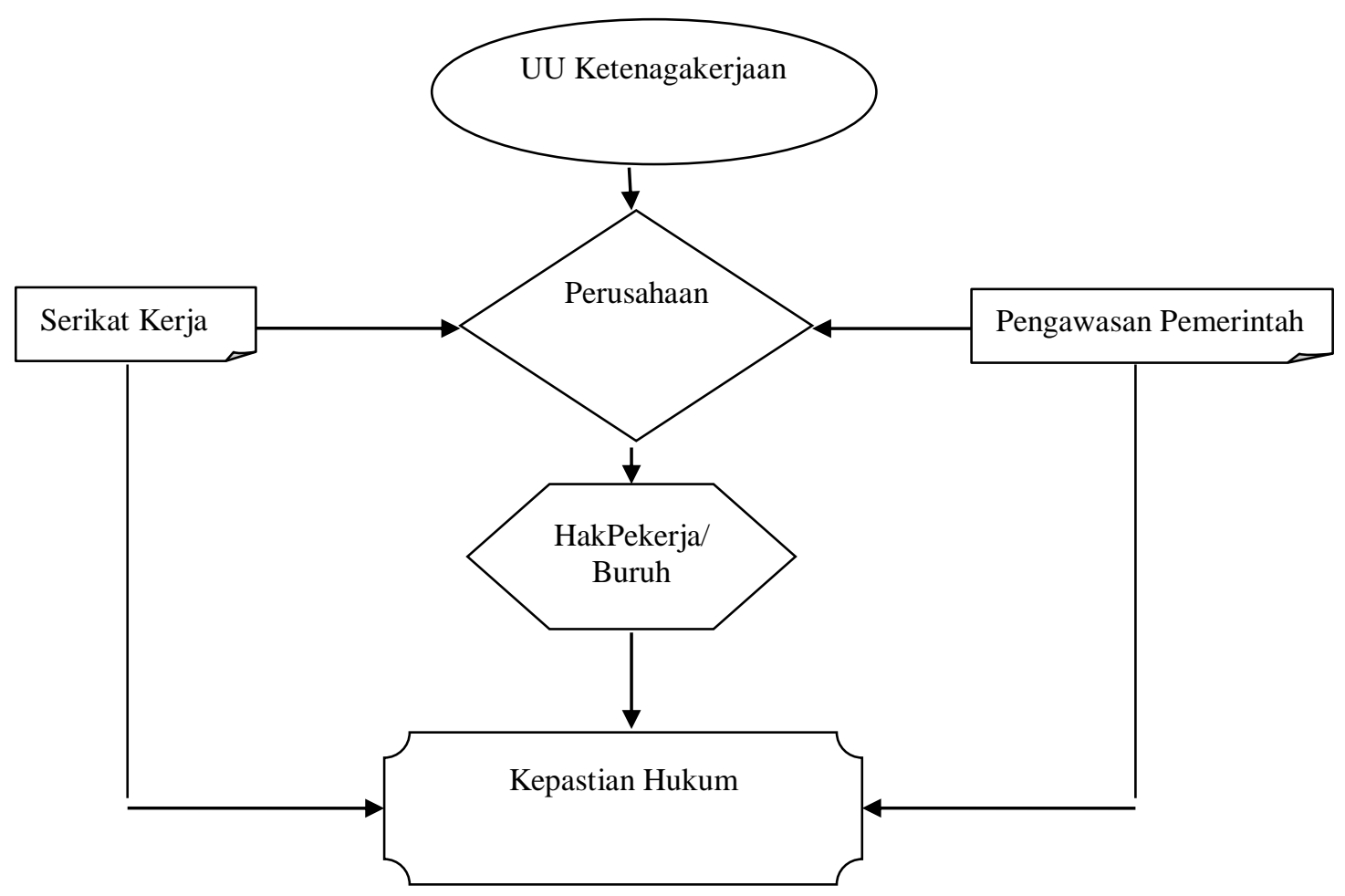

\section{METODE PENELITIAN}

Menurut Peter Mahmud Marzuki, dilihat dari segi keilmuan hukum yang bersifat deskriptif maka tipe penelitian dasar (fundamental research) berada diluar penelitian 
hukum, karena obyek kajiannya adalah masalah hukum sebagai gejala social bukan hukum sebagai norma social. Sedangkan doctrinal research, reform-oriented research, dan theoretical research merupakan penelitian hukum, karena memiliki karakter tersendiri yang tujuannya untuk mendapatkan pemahaman yang lebih dalam mengenai gejala hukum tertentu.( Peter Mahmud Marzuki,2005 : 33)

Sesuai dengan isu hukum yang telah ditetapkan dalam penelitian ini, maka tipe penelitian ini merupakan penelitian hukum (legal research), yaitu, suatu proses untuk menemukan aturan hukum, prinsip-prinsip hukum, maupun doktrin- doktrin hukum, menjaab isu hukum yang dihadapi. Penelitian hukum ini dilakukan untuk menghasilkan argumentasi, teori atau konsep baru sebagai preskripsi dalam menyelesaikan masalah yang dihadapi, atau mengikuti pendapat Terry Hutchingson, merupakan penelitian hukum dengan tipe reform-oriented research.

Berdasarkan pada isu hukum yang telah ditetapkan dan tujuan penelitian yang diinginkan maka pendekatan yang digunakan adalah Pendekatan undang-undang (statute approach), yaitu, menelaah semua undang-undang dan peraturan lain dalam bidang hukum ketenagakerjaan yang bersangkut dengan isu hukum dengan maksud untuk mencari ratio legis dan dasar antologis lahirnya undang-undang sehingga mampu mengangkat kandungan filosofis serta mempelajari konsistensi antara undang-undang dengan peraturan perundangan yang lainnya. Pendekatan konseptual (conceptual approach), yaitu, pendekatan yang beranjak dari pandangan-pandangan dan doktrindoktrin yang berkembang di dalam ilmu hukum, khususnya hukum acara perdata, sehingga dapat menemukan ide-ide yang melahirkan pengertian-pengertian hukum, konsep- konsep hukum, dan asas-asashukumyang relevan dengan isu hukum sehingga mampu membangun suatu argumentasi hukum dalam memecahkan isu hukum. Pendekatan kasus (case appproach), yaitu, menelaah kasus-kasus yang diputus oleh pengadilan berkaitan dengan isu yang dihadapi. Dalam pendekatan ini, yang akan ditelaah adalah ratio decidendi atau legal reasoning, yaitu, pertimbangan hakim untuk sampai kepada suatu putusan yang menjadi referensi dalam penyusunan argumentasi hukum dalam pemecahan isu hukum.

Tipe penelitian hukum ini merupakan penelitian yang berbasis kepustakaan (library based), yang berfokus pada analisis bahan hukum primer dan sekunder. Bahan hukum primer adalah sumber aktual dari hukum, yaitu, undang-undang dan putusan 
pengadilan (the primary materials are the actual sources of the law - the legislation and case law),( Terry Hutchinson 2002: 9) dalam hal ini antara lain: peraturan perundangundangan, yaitu: Undang-Undang No 13 tahun 2003 Tentang Ketenagakerjaan, dan peraturan yang berkaitan dengan ketenagakarjaan Sedangkan bahan hukum sekunder, adalah bahan yang meliputi komentar pada hukum yang ditemukan pada buku dan jurnal hukum (the secondary materials include he commentary on the law found in texbooks and legal journal), dalam hal ini antara lain: buku-buku teks, kamus-kamus hukum, jurnal-jurnal hukum.

Bahan hukum baik primer maupun sekunder diperoleh akan diinventarisasi dan diidentifikasi untuk selanjutnya dipergunakan dalam menganalisis permasalahan yang berhubungan dengan kajian penelitian ini. Dalam melakukan inventarisasi serta identifikasi bahan hukum digunakan sistem kartu (card system) yaitu dengan mengurutkan bahan-bahan hukum sebagai sumbernya, sehingga penatalaksanaan secara kritis, logis dan sistematis yang kemudian dilakukan analisis secara mendalam (in depth) atas fakta-fakta hukum hukum yang ditemukan. Dengan langkah-langkah demikian diharapkan akan lebih mempermudah alur penyesuaian penelitian ini. Setelah melalui tahapan- tahapan inventarisasi dan identifikasi terhadap sumber bahan hukum yang relevan (primer dan sekunder), langkah berikutnya melakukan sistematisasi keseluruhan bahan hukum yang ada. Proses sistematisasi ini juga diberlakukan terhadap teori-teori, konsep-konsep, doktrin serta bahan rujukan lainnya. Rangkaian tahapan inventarisasi, identifikasi dan sistematisasi tersebut dimaksudkan untuk mempermudah pengkajian dari permasalahan penelitian.

Analisis bahan hukum dalam penelitian ini, diawali: Pertama, melakukan identifikasi terhadap fakta-fakta hukum untuk menetapkan isu hukum yang hendak dipecahkan; Kedua, mengumpulkan bahan-bahanhukum(primer dan sekunder); Ketiga, melakukan telaah atas isu hukum yang diajukan berdasarkan bahan-bahan hukum yang telah dikumpulkan; Keempat, merumuskan kesimpulan dalam bentuk argumentasi menjawab isu hukum; dan Kelima, memberikan Diskripsi berdasarkan kesimpulan.

\section{HASIL DAN PEMBAHASAN}

\section{A. Pelaksanaan Perlindungan Tenga Kerja}

Undang-undang No. 13 Tahun 2003 tentang ketenagakerjaan mengatur syarat-syarat perusahaan yang dapat menyediakan tenaga kerja agar kepentingan 
para pihak yang terlibat, baik pihak-pihak yang berhubungan maupun terhadap pekerja/buruh yang dipekerjakan tidak ada yang dirugikan.

Syarat-syarat tersebut dalam Pasal 65 Undang-Undang No. 13 Tahun 2003 disebutkan:

1. Perusahaan penyedia tenaga kerja haus berbentuk badan hukum (Pasal 65 ayat (3))

2. Perusahaan penyedia tenaga kerja harus mampu memberikan perlindungan upah dan kesejahteraan, memenuhi syarat-syarat kerja sekurang-kurangnya sama dengan perusahaan pengguna tenaga kerja atau peraturan-perundang-undangan yang berlaku. (Pasal 65 ayat (4)), dengan kata lain perusahaan penyedia tenaga kerja minimal harus memiliki Peraturan Perusahaan yang telah disetujui oleh Departemen Tenaga Kerja.

Pasal 66 Undang-Undang No. 13 Tahun 2003 antara lain :

1. Ada hubungan kerja antara pekerja/buruh dengan perusahaan penyedia jasa pekerja/buruh;

2. Perjanjian kerja yang berlaku dalam hubungan kerja adalah perjanjian kerja untuk waktu tertentu yang memenuhi persyaratan sebagaimana terdapat dalam Pasal 59 Undang-Undang No. 13 Tahun 2003 dan/atau perjanjian kerja waktu tidak tertentu yang dibuat secara tertulis dan ditandatangani oleh kedua belah pihak.

3. Perlindungan upah dan kesejahteraan, syarat-syarat kerja, serta perselisihan yang timbul menjadi tanggung jawab perusahaan penyedia jasa pekerja/buruh.

4. Perjanjian antara perusahaan pengguna jasa pekerja/buruh dan perusahaan penyedia pekerja/buruh dibuat secara tertulis dan wajib memuat pasal sebagaimana dimaksud dalam undang-undang ini.

5. Penyedia jasa pekerja/buruh merupakan bentuk usaha yang berbadan hukum dan memiliki izin dari instansi yang bertanggung jawab di bidang ketenagakerjaan.

Kriminalisasi terhadap pekerja dan pemberangusan hak untuk berserikat. Dalam Catatan Akhir Tahun yang dirilis Lembaga Bantuan Hukum (LBH) Jakarta, 
tercatat selama 2015 ada 244 pengaduan untuk kasus perburuhan. Pada 2016 LBH Jakarta menangani lebih lanjut 41 kasus dengan 570 pencari keadilan. Pada 2017, LBH Jakarta bahkan menerima 223 pengaduan dengan 4.565 pencari keadilan (Internet, 5 Agustus 2019).

Perusahaan diwajibkan menjamin perlindungan/jaminan terhadap hak-hak pekerja/buruh.perlindungan tersebut dimulai dengan adanya kewajiban, bahwa perusahaan harus berbadan hukum. Bila kita berbicara masalah perlindungan kerja dan syarat-syarat kerja, maka hal ini merupakan masalah yang sangat komplek karena akan berkaitan dengan kesehatan kerja, keselamatan kerja, upah, kesejahteraan, dan jamsostek. Undang-Undang No. 13 tahun 2003 telah mengatur semua di dalam pasalpasalnya.

Menurut Soepomo, perlindungan tenaga kerja dibagi menjadi 3 (tiga ) macam, (Abdul khakim 2003: 61- 62) yaitu :

1. Perlindungan ekonomis, yaitu perlindungan tenaga kerja dalam bentuk penghasilan yang cukup, termasuk bila tenaga kerja tidak mampu bekerja di luar kehendaknya.

2. Perlindungan sosial, yaitu : perlindungan tenaga kerja dalam bentuk jaminan kesehatan kerja, dan kebebasan berserikat dan perlindungan hak untuk berorganisasi.

3. perlindungan teknis, yaitu : perlindungan tenaga kerja dalam bentuk keamanan dan keselamatan kerja.

Perlindungan tenaga kerja Undang-Undang No. 13 Tahun 2003 tentang Ketenagakerjaan mengatur perlindungan khusus pekerja/buruh perempuan, anak dan penyandang cacat sebagai berikut :

a) Perlindungan Anak

Pengusaha dilarang mempekerjakan anak (Pasal 68), yaitu setiap orang yang berumur dibawah 18 (delapan belas) tahun (Pasal 1 nomor 26). Ketentuan tersebut dapat dikecualikan bagi anak yang berumur antara 13 tahun sampai 15 tahun untuk melakukan pekerjaan ringan sepanjang tidak mengganggu perkembangan dari kesehatan fisik, mental dan sosial (Pasal 69 ayat( 1)). Pengusaha yang memperkerjakan anak pada pekerjaan ringan tersebut harus memenuhi persyaratan sebagai berikut: 
1. Ijin tertulis dari orang tua/wali.

2. Perjanjian kerja antara orang tua dan pengusaha

3. Waktu kerja maksimal 3 (tiga) jam

4. Dilakukan pada siang hari dan tidak mengganggu waktu sekolah.

5. Keselamatan dan kesehatan kerja

6. Adanya hubungan kerja yang jelas

7. Menerima upah sesuai ketentuan yang berlaku.

Dalam hal anak dipekerjakan bersama-sama pekerja/buruh dewasa, maka tempat kerja anak harus dipisahkan dari tempat kerja pekerja/buruh dewasa (Pasal 72). Anak dianggap bekerja bilamana berada di tempat kerja, kecuali dapat dibuktikan sebaliknya (Pasal 73). Siapapun dilarang mempekerjakan anak pada pekerjaan yang buruk, tercantum dalam Pasal 74 ayat (1). Yang dimaksud pekerjaan terburuk seperti dalam Pasal 74 ayat (2), yaitu :

1. Segala pekerjaan dalam bentuk pembudakan atau sejenisnya.

2. Segala pekerjaan yang memanfaatkan, menyediakan atau melibatkan anak untuk produksi dan perdagangan minuman keras,narkotika, psikotropika dan zat adiktif lainnya.

3. Segala pekerjaan yang memanfaatkan, menyediakan atau menawarkan anak untuk pelacuran, produksi pornografi, pertunjukan porno, perjudian.

4. Segala pekerjaan yang membahayakan kesehatan, keselamatan atau moral anak.

b) Perlindungan Pekerja/Buruh Perempuan

1. Pekerjaan wanita/perempuan di malam hari diatur dalam Pasal 76 yaitu sebagai berikut :

a. Pekerjaan perempuan yang berumur kurang dari 18 tahun dilarang dipekerjakan antara pukul 23.00 sampai dengan pukul 07.00 pagi.

b. Pengusaha dilarang mempekerjakan pekerja perempuan hamil yang menurut keterangan dokter berbahaya bagi kesehatan dan keselamatan kandungannya maupun dirinya, bila bekerja antara pukul 23.00 sampai dengan pukul 07.00 pagi.

c. Pengusaha yang mempekerjakan pekerja perempuan antara pukul 23.00 sampai dengan pukul 07.00 pagi wajib : 
1) Memberikan makanan dan minuman bergizi b. Menjaga kesusilaan dan keamanan selama di tempat kerja

2) Pengusaha yang mempekerjakan pekerja perempuan antara pukul 23.00 sampai dengan pukul 05.00 pagi wajib menyediakan antar jemput.

3) Tidak mempekerjakan tenaga kerja melebihi ketentuan Pasal 77 ayat (2) yaitu 7 (tujuh) jam sehari dan 40 (empat puluh) jam seminggu untuk 6 (enam) hari kerja dalam seminggu atau 8 (delapan) jam sehari dan 40 (empat puluh) jam seminggu untuk 5 (lima) hari kerja dalam seminggu.

4) Bila pekerjaan membutuhkan waktu yang lebih lama, maka harus ada persetujuan dari tenaga kerja dan hanya dapat dilakukan paling banyak 3 (tiga) jam dalam sehari dan 14 (empat belas) jam dalam seminggu, dan karena itu pengusaha wajib membayar upah kerja lembur untuk kelebihan jam kerja tersebut. Hal ini merupakan ketentuan dalam Pasal 78 ayat (1) dan ayat (2).

5) Tenaga kerja berhak atas waktu istirahat yang telah diatur dalam Pasal 79 ayat (2) yang meliputi waktu istirahat untuk:

a. Istirahat antara jam kerja, sekurang-kurangnya setengah jam setelah bekerja selama 4 (empat) jam terus menerus dan waktu istirahat tersebut tidak termasuk jam kerja.

b. Istirahat mingguan 1 (satu) hari untuk 6 (enam) hari kerja dalam seminggu atau 2 (dua) hari untuk 5 (lima) hari kerja dalam seminggu.

c. Cuti tahunan sekurang-kurangnya 12 (dua belas hari kerja setelah tenaga kerja bekerja selama 12 (dua belas) bulan secara terus menerus.

d. Istirahat panjang sekurang-kurangnya 2 (dua) bulan apabila tenaga kerja telah bekerja selama 6 (enam) tahun secara terus menerus pada perusahaan yang sama dengan ketentuan tenaga kerja tersebut tidak berhak lagi istirahat tahunannya dalam 2 (dua) tahun berjalan.

6) Untuk pekerja wanita, terdapat beberapa hak khusus sesuai dengan kodrat kewanitaannya, yaitu : 
a. Pekerja wanita yang mengambil cuti haid tidak wajib bekerja pada hari pertama dan kedua (Pasal 81 ayat (1))

b. Pekerja wanita berhak memperoleh istirahat selama 1,5 bulan sebelum saatnya melahirkan dan 1,5 bulan sesudah melahirkan menurut perhitungan dokter kandungan/bidan (Pasal 82 ayat (1))

c. Pekerja wanita yang mengalami keguguran kandungan berhak memperoleh istirahat 1,5 bulan sesuai ketentuan dokter kandungan/bidan (Pasal 82 (2)).

d. Pekerja wanita yang anaknya masih menyusui harus diberi kesempatan sepatutnya untuk menyusui anaknya jika hal itu harus dilakukan selama waktu kerja (Pasal 83)

e. Pekerja wanita yang mengambil cuti hamil berhak mendapat upah penuh (Pasal 84).

c) Keselamatan dan kesehatan kerja Keselamatan kerja merupakan salah satu hak pekerja/buruh (Pasal 86 ayat (1) huruf a Undang-Undang Nomor 13 Tahun 2003.

Untuk itu pengusaha wajib melaksanakan secara sistematis dan terintegrasi dengan sistem managemen perusahaan. Upaya keselamatan dan kesehatan kerja bertujuan untuk melindungi keselamatan pekerja/buruh guna mewujudkan produktivitas kerja yang optimal, dengan cara pencegahan kecelakaan dan penyakit akibat kerja, pengendalian bahaya di tempat kerja, promosi kesehatan, pengobatan dan rehabilitasi. Begitu pentingnya keselamatan kerja ini bagi tenaga kerja, maka Undang-Undang No. 13 Tahun 2003 mengatur dalam Pasal 86 ayat (1), yaitu : Setiap pekerja/buruh mempunyai hak untuk memperoleh perlindungan atas :

1. Keselamatan dan kesehatan kerja;

2. Moral dan kesusilaan; dan

3. Perlakuan yang sesuai dengan harkat dan martabat manusia serta nilai-nilai agama.

Ketentuan tentang keselamatan kerja diatur dalam UndangUndang No. 1 tahun 1970 tentang Keselamatan Kerja. Keselamatan kerja yang dimaksud adalah keselamatan kerja dalam segala tempat kerja, baik di darat, di dalam tanah, di permukaan air, di dalam air maupun di udara, yang berada di dalam wilayah kekuasaan hukum Republik Indonesia. (Pasal 2 ayat (1)). 
Ketentuan tersebut di atas berlaku di dalam tempat kerja tertentu, seperti yang diatur dalam Pasal 2 ayat (2)) sebagai berikut : Ketentuan-ketentuan dalam ayat (1) tersebut berlaku dalam tempat kerja dimana :

a. Dibuat, dicoba, dipakai atau dipergunakan mesin, pesawat, alat, perkakas, peralatan atau instalasi yang berbahaya atau dapat menimbulkan kecelakaan, kebakaran atau peledakan;

b. Dibuat, diolah, dipakai, dipergunakan, diperdagangkan, diangkut atau disimpan bahan atau barang, yang dapat meledak, mudah terbakar, menggigit, beracun, menimbulkan infeksi, bersuhu tinggi;

c. Dikerjakan pembangunan, perbaikan, perawatan, pembersihan atau pembongkaran rumah, gedung atau bangunan lainnya, termasuk bangunanbangunan pengairan, saluran atau terowongan di bawah tanah dan sebagainya atau dimana dilakukan pekerjaan persiapan;

d. Dilakukan usaha : pertanian, perkebunan, pembukaan hutan, pengerjaan hutan, pengolahan kayu atau hasil hutan lainnya, peternakan, perikanan dan lapangan kesehatan;

e. Dilakukan usaha pertambangan dan pengolahan : emas, perak, logam atau bijih logam lainnya, batu-batuan, gas, minyak atau mineral lainnya, baik dipermukaan atau di dalam bumi, maupun didasar perairan;

f. Dilakukan pengangkutan barang, binatang atau manusia, baik di daratan, melalui terowongan, di permukaan air dalam air maupun di udara;

g. Dikerjakan bongkar muat barang muatan di kapal, perahu, dermaga, dok, stasiun atau gudang;

h. Dilakukan penyelaman, pengambilan benda dan pekerjaan lain di dalam air;

i. Dilakukan pekerjaan dalam ketinggian di atas permukaan tanah atau perairan;

j. Dilakukan pekerjaan di bawah tekanan udara atau suhu yang tinggi atau rendah;

k. Dilakukan pekerjaan yang mengandung bahaya tertimbun tanah, kejatuhan, terkena pelantingan benda, terjatuh atau terperosok, hanyut atau terpelanting;

1. Dilakukan pekerjaan dalam tangki, sumur atau lubang;

m. Terdapat atau menyebar suhu, kelembaban, debu, kotoran, api, asap, uap, gas, hembusan angin, cuaca, sinar atau radiasi suara atau getaran;

n. Dilakukan pembuangan atau pemusnahan sampah atau limbah; 
o. Dilakukan pemancaran, penyiaran atau penerimaan radio, radar, televisi, atau telepon;

p. Dilakukan pendidikan, pembinaan, percobaan, penyelidikan atau riset dan observasi dengan menggunakan alat teknik;

q. Dibangkitkan, dirubah, dikumpulkan, disimpan, dibagi-bagikan atau disalurkan listrik, gas, minyak atau air;

r. Diputar film, dipertunjukan sandiwara atau diselenggarakan rekreasi lainnya yang memakai peralatan, instalasi listri atau mekanik.

d) Upah

Kewajiban dari perusahaan sebagai akibat dari timbulnya hubungan kerja adalah membayar upah. Secara umum upah adalah pembayaran yang diterima buruh selama ia melakukan pekerjaan atau dipandang melakukan pekerjaan(Zainal Asikin, 1993 :86). Nurimansyah Haribuan mengatakan : "Upah adalah segala macam bentuk penghasilan (carning), yang diterima buruh/pegawai (tenaga kerja) baik berupa uang ataupun barang dalam jangka waktu tertentu pada suatu kegiatan ekonomi (Hasibuan Nurimansyah, 1981: 3).

Agar tenaga kerja dapat hidup dengan layak maka diatur perlindungan hukum mengenai upah sesuai dengan Pasal 27 ayat (2) undang-Undang dasar 1945 yaitub : "Setiap warga negara berhak atas pekerjaan penghidupan yang layak bagi kemanusiaan." Pasal ini dijabarkan lebih lanjut dalam Undang-Undang No. 13 Tahun 2003 tentang Ketenagakerjaan yaitu pada Pasal 88 ayat (1) : “ setiap pekerja/buruh berhak memperoleh penghasilan yang memenuhi penghidupan yang layak bagi kemanusiaan." Yang dimaksud dengan penghasilan yang memenuhi penghidupan yang layak adalah jumlah penerimaan atau pendapatan pekerja/buruh dari hasil pekerjaannya mampu memenuhi kebutuhan hidup pekerja/buruh dan keluarganya secara wajar yang meliputi makanan dan minuman, sandang, perumahan, pendidikan, kesehatan, rekreasi dan jaminan hari tua. Pengupahan lebih lanjut diuraikan dalam Undang-Undang No. 13 Tahun 2003 tentang Ketenagakerjaan, antara lain :

1. Menetapkan kebijakan pengupahan dalam pasal 88 ayat (2) dan (3), yang meliputi : upah minimum, upah kerja lembur, upah tidak masuk kerja karena 
berhalangan, upah tidak masuk kerja karena melakukan kegiatan lain di luar pekerjaannya, upah karena menjalankan hak waktu istirahat kerjanya, bentuk dan cara pembayaran upah, denda dan potongan upah, hal-hal yang dapat diperhitungkan dengan upah, struktur dan skala pengupahan perhitungan pajak penghasilan.

2. Upah minimum berdasarkan wilayah propinsi atau kabupaten/kota dan berdasarkan sektor wilayah propinsi atau kabupaten/kota. (Pasal 89 ayat (1). Pengusaha dilarang membayar upah lebih rendah dari upah minimum (Pasal 90 ayat (1)).

3. Upah tidak dibayar bila pekerja tidak melakukan pekerjaan. (Pasal 93 ayat (1). Ketentuan ini merupakan asas yang pada dasarnya berlaku untuk semua buruh/pekerja, kecuali bila pekerja/buruh yang bersangkutan tidak dapat melakukan pekerjaan bukan karena kesalahannya.

4. Beberapa pengecualian dari Pasal 93 ayat (1) tercantum dalam Pasal 93 ayat (2), yaitu : Ketentuan sebagaimana dimaksud pada ayat (1) tidak berlaku, dan pengusaha diwajibkan membayar upah apabila :

a. pekerja/buruh sakit termasuk pekerja/buruh perempuan yang sakit pada hari pertama dan kedua masa haidnya sehingga tidak dapat melakukan pekerjaan. Hal ini dapat dibuktikan dengan surat keterangan dokter.

b. Pekerja/buruh tidak masuk kerja karena menikah, menikahkan, mengkhitankan, membaptiskan anaknya, isteri melahirkan atau keguguran kandungan, suami atau isteri atau anak atau menantu atau mertua atau orang tua atau anggota keluarga dalam satu rumah meninggal dunia

c. Pekerja/buruh tidak dapat melakukan pekerjaannya karena sedang menjalankan kewajiban terhadap negara.

d. Pekerja/buruh tidak dapat melakukan pekerjaannya karena menjalankan ibadah yang diperintahkan agamanya;

e. Pekerja/buruh bersedia melakukan pekerjaan yang telah dijanjikan tetapi pengusaha tidak mempekerjakannya, baik karena kesalahan sendiri maupun halangan yang seharusnya dapat dihindari pengusaha;

f. Pekerja/buruh melaksanakan hak istirahat; 
g. Pekerja/buruh melaksanakan tugas serikat pekerja/serikat buruh atas persetujuan pengusaha; dan

h. Pekerja/buruh melaksanakan tugas pendidikan dari perusahaan.

5. Tenaga kerja yang mengalami sakit sehingga tidak dapat melaksanakan tugasnya tetap memiliki hak atas upah, seperti yang diatur dalam pasal 93 ayat (3), sebagai berikut :

a. untuk 4 (empat) bulan pertama, dibayar $100 \%$ (seratus perseratus) dari upah;

b. untuk 4 (empat) bulan kedua, dibayar $75 \%$ (tujuh puluh lima perseratus) dari upah;

c. untuk 4 (empat) bulan ketiga, dibayar $50 \%$ (lima puluh perseratus) dari upah; dan

d. untuk bulanselanjutnya dibayar $25 \%$ (dua puluh lima perseratus) dari upah sebelum pemutusan hubungan kerja dilakukan oleh pengusaha.

6. Komponen upah terdiri dari upah pokok dan tunjangan tetap dengan besarnya upah pokok sedikit-dikitnya $75 \%$ (tujuh puluh lima perseratus) dari jumlah pokok dan tunjangan tetap. Diatur dalam Pasal 94. Yang dimaksud dengan tunjangan tetap adalah pembayaran kepada pekerja/buruh yang dilakukan secara teratur dan tidak dikaitkan dengan kehadiran pekerja/buruh atau pencapaian prestasi kerja tertentu.

e) Kesejahteraan

Menyadari akan pentingnya pekerja bagi perusahaan, perusahaan wajib untuk untuk menjamin kesejahteraan dari tenaga kerja, Undang-Undang No. 13 Tahun 2003 telah mengatur sebagai berikut:

1. Setiap pekerja/buruh dan keluarganya berhak untuk memperoleh jaminan sosial tenaga kerja. (Pasal 99 ayat (1)).

2. Untuk meningkatkan kesejahteraan bagi pekerja/buruh dan keluarganya, pengusaha wajib menyediakan fasilitas kesejahteraan yang meliputi pelayanan keluarga berencana, tempat penitipan anak, perumahan pekerja/buruh, fasilitas beribadah, fasilitas olahraga, fasilitas kantin, fasilitas kesehatan dan fasilitas rekreasi tentunya penyediaan fasilitas tersebut dilaksanakan dengan 
memperhatikan kebutuhan pekerja/buruh dan ukuran kemampuan perusahaan. (Pasal 100 ayat (1) dan ayat (2))

3. Untuk meningkatkan kesejahteraan pekerja/buruh dibentuk koperasi pekerja/buruh dan usaha-usaha produktif di perusahaan yaitu kegiatan yang bersifat ekonomis yang menghasilkan pendapatan diluar upah. (Pasal 101 ayat (1)).

f) Jamsostek

Program Jaminan Sosial Tenaga Kerja (Program Jamsostek) merupakan bentuk perlindungan ekonomis dan perlindungan sosial. Dikatakan demikian karena program ini memberikan perlindungan dalam bentuk santunan berupa uang atas berkurangnya penghasilan dan perlindungan dalam bentuk pelayanan dan perawatan/pengobatan pada saat seorang pekerja tertimpa risiko-risiko tertentu. Program Jamsostek merupakan kelanjutan dari program Asuransi Sosial Tenaga Kerja (ASTEK) yang didirikan menurut Peraturan Pemerintah Nomor 33 Tahun 1977. Secara yuridis penyelenggaraan program Jamsostek dimaksudkan sebagai pelaksana Pasal 10 dan Pasal 15 Undang-Undang Nomor 14 Tahun 1969 tentang Ketentuan-ketentuan Pokok mengenai Tenaga Kerja (yang sekarang sudah dicabut dan diganti dengan Undang-Undang Nomor 13 Tahun 2003 tentang Ketenagakerjaan, yang diatur dalam Pasal 99 yang pelaksanaannya sementara ini masih mengikuti ketentuan dalam Undang-Undang Nomor 3 Tahun 1992 tentang Jaminan Sosial Tenaga Kerja (JAMSOSTEK) berikut aturan pelaksanaannya yaitu PP No. 14 tahun 1993, PP No, 64 tahun 2005 tentang perubahan ke empat atas PP No, 14 Tahun 1993 tentang Penyelenggaraan Jamsostek. Program Jamsostek meliputi jaminan Kematian, Jaminan Kecelakaan Kerja, Jaminan Hari Tua dan Jaminan Pemeliharaan Kesehatan. Penyelenggaraan Program Jamsostek diwajibkan bagi pengusaha yang memiliki tenaga kerja minimal 10 (sepuluh) orang.

\section{B. Kepastian Hukum Tenaga Kerja}

Pekerja/buruh sebagai warga negara mempunyai persamaan kedudukan dalam hukum, hak untuk mendapatkan pekerjaan dan penghidupan yang layak, mengeluarkan pendapat, berkumpul dalam suatu organisasi, serta mendirikan dan 
menjadi anggota serikat pekerja/serikat buruh. Hak menjadi anggota serikat pekerja/serikat buruh merupakan hak asasi pekerja/buruh yang telah dijamin dalam Pasal 28 UUD 1945. Diratifikasi oleh Pemerintah Republik Indonesia Konvensi ILO No. 87 tentang Kebebasan Berserikat dan Perlindungan Hak Untuk Berorganisasi, dan Konvensi ILO No. 98 mengenai berlakunya Dasar-dasar untuk Berorganisasi dan untuk berunding bersama. Kedua konvensi tersebut sebagai dasar hukum bagi pekerja/buruh untuk berorganisasi dengan mendirikan serikat pekerja/serikat buruh. Lemahnya Pekerja/buruh dilihat dari segi ekonomi maupun juga kedudukannya dan pengaruhnya terhadap pengusaha, karena itu akibatnya Pekerja/buruh tidak mungkin bisa memperjuangkan hak-haknya ataupun tujuannya secara perorangan tanpa mengorganisasi dirinya dalam suatu wadah untuk dapat mencapai tujuannya. Wadah yang dimaksudkan disebut serikat pekerja/serikat buruh sebagaimana yang telah diatur dalam Undang-Undang Nomor 21 Tahun 2000 tentang Serikat Pekerja/Serikat buruh. Pasal 1 angka 17 Undang-Undang No. 23 Tahun 2003, jo Pasal 1 angka 1 Undang-Undang No. 21 Tahun 2000 tentang serikat Pekerja/Serikat buruh menjelaskan, serikat Pekerja/Serikat buruh adalah organisasi yang dibentuk dari, oleh, dan untuk pekerja/buruh, baik di perusahaan maupun diluar perusahaan, yang bersifat bebas, terbuka, mandiri, demokratis, dan bertanggung jawab guna memperjuangkan, membela, serta melindungi hak dan kepentingan pekerja/buruh serta meningkatkan kesejahteraan pekerja/buruh dan keluarganya.( Zaeni Asyhadie, 2007: 22-23)

Asas Serikat Pekerja Serikat Pekerja/Serikat buruh, federasi serikat Pekerja/Serikat buruh, konfederasi serikat Pekerja/Serikat buruh harus menerima Pancasila sebagai Dasar Negara dan Undang-Undang dasar 1945 sebagai konstitusi Negara dan Undang-Undang Dasar 1945 sebagai konstitusi Negara Kesatuan Republik Indonesia. Oleh karena itu, asas pendirian suatu serikat pekerja/serikat buruh adalah tidak boleh bertentangan dengan Pancasila dan UUD’1945.

Tujuan Serikat Pekerja Tujuan Serikat Pekerja/Serikat buruh, federasi serikat Pekerja/Serikat buruh, konfederasi serikat Pekerja/Serikat buruh adalah memberikan perlindungan, pembelaan hak dan kepentingan, serta meningkatkan kesejahteraan yang layak bagi pekerja/buruh dan keluarganya, dengan 2 (dua) tujuan ke luar dan ke dalam. Tujuan keluar yaitu meningkatkan kesejahteraan yang 
layak bagi pekerja/buruh dan keluarganya, sedangkan tujuan kedalam adalah memberikan perlindungan, pembelaan hak dan kepentingan pekerja/buruh dari pengusaha.

Fungsi Serikat Pekerja Dalam Pasal 4 ayat (2) Undang-Undang No. 21 Tahun 2000 Fungsi serikat Pekerja/Serikat buruh, federasi serikat Pekerja/Serikat buruh, konfederasi serikat Pekerja/Serikat buruh adalah :

a. Sebagai pihak dalam pembuatan perjanjiankerja bersama dan penyelesaian perselisihan industrial;

b. Sebagai wakil pekerja/buruh dalam lembaga kerja sama di bidang ketenagakerjaan sesuai dengan tingkatannya;

c. Sebagai sarana menciptakan hubungan industrial yang harmonis, dinamis, dan berkeadilan sesuai dengan peraturan perundangundangan yang berlaku;

d. Sebagai sarana penyalur aspirasi dalam memperjuangkan hak dan kepentingan anggotanya;

e. Sebagai perencana, pelaksana, dan penanggung jawab pemogokan pekerja/buruh sesuai dengan peraturan perundang-undangan yang berlaku;

f. Sebagai wakil pekerja/buruh dalam memperjuangkan kepemilikan saham di perusahaan.

\section{SIMPULAN DAN SARAN}

\section{Simpulan}

Berdasarkan data-data yang diperoleh dapat disimpulkan : Dalam perlindungan kerja yang telah terpenuhi baru ketentuan pekerja anak, ketentuan Pasal 68 sampai dengan Pasal 75 tentang pekerja anak, Pasal 76 tentang jam kerja malam bagi pekerja wanita, Pasal 81-83 tentang hak-hak khusus pekerja wanita. Selain itu waktu isitirahat yang diberikan kepada tenaga kerja dan ketentuan kelebihan jam kerja belum memenuhi ketentuan Pasal 78 ayat (1) dan ayat (2). Jam kerja yang diberlakukan bila dijumlah dalam 1 (satu) minggu jumlahnya adalah 45 (empat puluh lima) jam padahal dalam Pasal 77 ayat (2) maksimal jam kerja perminggu adalah 40 (empat puluh) jam. Uang makan lembur tidak diberikan karena kurang dari 4 jam nyata pada hari-hari kerja. Hal ini melanggar pasal 77 ayat (2) yang telah mengatur bahwa total jam kerja nyata dalam 
seminggunya tidak boleh lebih dari 40 (empat puluh) jam. Dan ketentuan Waktu Kerja Lembur dalam Undang-Undang Nomor 13 Tahun 2003 Tentang Ketenagakerjaan Pasal 78 ayat (1) huruf b yaitu hanya dapat dilakukan paling banyak 3 (tiga) jam dalam 1(satu) hari dan 14 (empat belas) jam dalam 1 (satu) minggu. Begitu juga dengan Ketentuan yang menyebutkan bahwa Khusus untuk tenaga shift tidak mendapat uang makan lembur dan uang transport lembur apabila bekerja pada hari-hari libur resmi, tidak sesuai dengan ketentuan Waktu Kerja Lembur dalam Undang-Undang Nomor 13 Tahun 2003 Tentang Ketenagakerjaan Pasal 78 ayat (2) yang menyebutkan bahwa Pengusaha yang mempekerjakan pekerja/buruh melebihi waktu kerja sebagaimana dimaksud pada ayat (1) wajib membayar upak kerja lembur. perlindungan social tersebut tidak bisa memberikan perlindungan dan kesejahteraan yang maksimal, keanggotaan jamsostek bagi Perusahaan hanya dianggap sebagai persyaratan yang diperlukan dalam proses penagihan tanpa melihat manfaat yang diperoleh para pekerja dari keikutsertaannya dalam keanggotaan Jamsostek. Dengan demikian Perlindungan Hukum bagi Pekerja masih belum maksimal dan masih sangat lemah.

\section{Saran}

1. Harus ada pengawasan terhadap perusahaan yang lebih di perketat supaya pekerja lebih terlindungi.

2. Hendaknya perusahaan segera memenuhi ketentuan yang berlaku dalam rangka memperbaiki sistem kerja sesuai dengan ketentuan yang ada dalam UndangUndang Nomor 13 Tahun 2003 Tentang ketenagakerjaan, diantaranya :

a. Harus adanya jadwal kerja dan lembur bagi tenaga kerja yang jelas agar memenuhi ketentuan 40 (empat puluh) jam seminggu atau membayar kelebihan jam kerja setiap harinya dengan upah lembur sesuai dengan ketentuan yang berlaku.

b. Upah dan tunjangan-tunjangan yang diberikan sebaiknya disesuaikan dengan Upah Minimum kota/Kabupaten dan juga Surat Perjanjian Kerja (SPK) yang telah disepalati 
c. Harus adanya perbaikan untuk Program Jamsostek, dengan cara Seluruh pembayaran setiap bulan program Jamsostek sebesar 10,8 \% X upah tetap perbulan untuk setiap bulannya menjadi beban perusahaan.

d. Harus membuat atau mengikutsertakan para pekerjanya dalam program asuransi yang lain yang lebih menjamin kesejahteraan bagi para pekerja selain dari Program Jamsostek yang dianggap terlalu mempersulit dan membebani para Pekerja.

\section{DAFTAR PUSTAKA}

\section{Buku:}

Abdul khakim, Pengantar Hukum Ketenagakerjaan Indonesia, Jakarta : Citra Aditya Bakti 2003.

FX Djumiadji, Perjanjian Pemborongan, Jakarta : Penerbit Bina Aksara, 1987.

Hasibuan Nurimansyah, Upah Tenaga Kerja dan Konsentrasi pada Sektor Industri, Prisma, No. 5 Th. X Mei 1981.

Lalu Husni, Hukum Ketenagakerjaan Indonesia, Jakarta : RajaGrafindo Persada, 2007

Peter Mahmud Marzuki, Penelitian Hukum, Prenada Media, Jakarta, 2005.

Terry Hutchinson, Resarching and Writing in Law, National Library of Australia, Sydney,2002

Zaeni Asyhadie, Hukum Kerja, Jakarta : RajaGrafindo Persada, 2007

Zainal Asikin, Agusfian wahab, Dasar-Dasar Hukum Perburuhan, Jakarta : RajaGrafindo, 1993

\section{Jurnal}

Agus Pramono, "Qua Vadis Perpolisian Komunitas (Community Policing)".Jurnal Masalahmasalah Hukum, Vol. 40 No. 4.Oktober 2011. Semarang: FH Universitas Diponogoro

\section{Internet :}

https://tirto.id/buruknya-jaminan-hak-pekerja-indonesia-cHeC, Di Akses Pada Tgl. 5 Agustus 2019 
Majalah Ilmiah Solusi

Vol. 17, No. 4 Oktober 2019

ISSN : 1412-5331

Halaman ini sengaja dikosongkan 